\section{Economic Aspects of the Cotton Trade}

"World Cotton Production and Trade" is the first of a series of studies of the principal agricultural products on the world market to be published by the International Institute of Agriculture, Rome (price 30 lire). This comprehensive monograph, consisting of 480 pages and 20 maps and diagrams, is divided into four main sections. The first deals with the geography of cotton production, describing the agricultural conditions of the humid and subhumid zones of the rain-grown crop, and the arid or semi-arid zone of irrigated cotton. Part 2 describes the conditions of cotton marketing and movements of cotton prices, while Part 3 is concerned with the evolution of world cotton trade. The fourth part deals with the national and international aspects of the industry, separate sections being devoted to the principal countries concerned. It is evident that the economic problems of the cotton trade are closely linked up with the wider financial and commercial problems of the world. The relatively large expansion of the smaller cotton countries during an economic crisis simultaneously with the general contraction of the world cotton industry, presents one of the most significant aspects of the world economic problem. The position was aggravated by the policy of the United States of maintaining cotton prices at an artificially high level and closing their market to European goods. It is considered that from the point of view of a rational world economic system, the various branches of agriculture should be developed in those parts of the world which are most suitable. Under such a system the United States would regain its position on the world cotton market, which is regarded as its full right, but the conditions of such a recovery would be the abandonment in all countries of the prevailing tendency towards economic isolation and a development of a greater degree of international co-operation.

\section{Progress in the Meteorological Office}

THF eighty-second year of the Meteorological Office is referred to in the annual report of the Director for the year ended March 31, 1937, as one of planning and preparation with the object of providing the greatly extended meteorological services required by the expanding Royal Air Force and by the increase of flying on civil air routes. These projected increases of meteorological activity have made it necessary for new staff to be recruited and trained in the special work required of them; in particular, the need for trained forecasters has had to be met in order to staff the principal forecasting centres on the various flying routes. The new Empire Air Mail Scheme led to the formation of a new division of the Meteorological Office in 1935 to organize the meteorological services of the trans-Atlantic and Empire air routes, the duty of advising the Govermments of territories traversed by the routes having devolved on the Meteorological Office, and throughout the year under review that division was preparing for the new mail service. The forecast and aviation division has given particular attention to the information required by civil and
R.A.F. aircraft in connexion with flying in and through clouds-information about the winds to be expected and warnings of dangerous conditions likely to lead to ice accretion between certain heights in strata where temperature lies between $0^{\circ} \mathrm{F}$. and $35^{\circ}$ F. and other circumstances are favourable for such accretion. It has now been determined that really dangerous conditions are scarcely ever found when temperature is more than a few degrees above or below the freezing point.

\section{Motor Traffic and Wild Life}

IN a discursive and interesting paper read before the Zoological Society of London (Proc. Zoo. Soc., Ser. A, 173 ; 1937), Surgeon Rear-Admiral Beadnell has given an indication of the destruction of wild creatures caused by motor traffic in Great Britain. In the years 1932-36, in travelling by motor-car and pedal-cycle on roads in England, Wales and Scotland, he counted 2327 dead animals in 10,000 miles, or 23 in every hundred miles. The kill was made up in the following proportions: birds 81 per cent (1885 individuals), rabbits 14 per cent, hedgehogs 4 per cent, rats 0.5 per cent, and the remainder was made up of frogs, toads, moles, snakes, dogs, cats, two sheep and one forest pony. It may be taken that the number counted during a rapid survey falls far short of the total number slain, and indeed were it not that many motorists when driving are highly regardful of wild creatures, the number would be much greater than it is. But the count does not suggest that motor traffic will make appreciable inroads upon the stock of wild animals, for the numbers are insignificant compared with the rate of increase of the common species which usually fall victims. An odd death which came to the notice of the writer was that of a dog fox in beautiful pelage, which during a snowstorm in the north-east of Scotland leapt over a stone wall against the wings of a heavy lorry.

\section{Policy in Pig-Feeding}

THE pig and bacon industry in Great Britain is dependent upon imported and home-grown cereals, and during the last twelve months feeding costs have risen by 30 per cent without a compensating rise in the price of bacon. The Bacon Development Board has accordingly completed an inquiry into the possibility of replacing cereals by other foodstuffs, and the report of A. N. Duckham has been published as Bulletin No. 2, "Substitutes for Cereals in PigKeeping" (Bacon Development Board, 1937. Price $2 s$.). The general conclusion is that if some sacrifice of growth rates and carcass quality is allowed and adequate facilities for growing and storing substitutes are made available, then cereals may be replaced in part by potatoes, sugar-beet and other home-grown root and fodder crops or by-products either in fresh or processed forms. At present, the use of these cereal substitutes may not be economical in Great Britain, but conditions may arise when cereals, home produced or imported, may be in short supply or at greater cost, and under such conditions it is 
believed that pig production could be kept up as an economic proposition, making an appreciable contribution to the national supply of meat and animal fat for human consumption.

\section{Water-Power of the World}

THE United States Geological Survey has attempted a new estimate of the potential and developed waterpower resources of the world. The estimate is based on ordinary medium flow and 100 per cent efficiency. Potential power is based on existing flow and disregards storage except in the case of constructed reservoirs. The estimates for developed power are based on installed capacity of machinery at constructed plants, which averages two or three times the potential power at low flow at the same sites. Thus, for example, the potential power at utilized sites in France amounts to 21 per cent of the total potential power of that country, but in effect amounts to 44 per cent of the theoretical total power resources. With this proviso, it is noted that about ten per cent of the potential water-power of the world is developed. The capacity of the constructed plant in the world at the end of 1936 was 60 million horsepower, or an increase of 160 per cent in sixteen years. The United States show by far the greatest development, but Canada, France, Italy and Japan have high figures, and Norway, Germany, Sweden, Switzerland and the Soviet Union show rising totals.

\section{Biochemistry in India}

THE Society of Biological Chemists, India, publishes a useful review each year of the results of investigations in biochemical subjects which have been carried out in India during the previous twelve months. The current number (Annual Review of Biochemical and Allied Research in India, 7, 1936. Pp. 165. (Bangalore : Society of Biological Chemists, India, 1937.) 3s.) is divided into seventeen sections, of which about two-thirds are devoted to various aspects of agricultural science. Sections are also given to vitamins and hormones, pharmacology and human physiology, pathology and bacteriology. The papers reviewed have, of course, been published in full in other journals, chiefly Indian, but this volume provides a useful summary of work which is not always easily accessible. It is noticeable that the size of the volume has been increased considerably since this review was first published, a tribute to the steady progress research is making in India.

\section{Diseases of Fur Animals}

ThE United States Department of Agriculture, Washington, D.C., in Farmer's Bulletin No. 1777, gives an account of the diseases attacking fur-animals on the farm, together with methods of control. Descriptions are given of distemper, paratyphoid infection and encephalitis of foxes, of hookworm, tapeworm and fluke affections, and of external parasites such as fleas, lice and sarcoptic mange, as well as of nutritional disturbances. Useful information is also given on farm sites and structure, their sanitation and disinfection. The Bulletin should be of value to those engaged in the fur industry in Great Britain.

\section{Fire at Messrs. Flatters and Garnett, Ltd.}

A serious fire occurred on Sunday morning, December 19, at the laboratories of Messrs. Flatters and Garnett, Ltd., the well-known Manchester firm of microscopists. The chemical and microscopical laboratories were completely burnt out, but a con. siderable number of mounted slides were saved. The photographic and lantern slide department was only slightly involved and the new instrument workshop, for manufacturing microscopes, micro-projectors, etc., escaped entirely. All the staff is being retained, and work has already been resumed in temporary laboratories. Stocks of most of the firm's chemical specialities are held at the head office, 309 Oxford Road, Manchester, 13, which is two miles from the laboratories.

\section{Awards of the Institution of Naval Architects}

THE Council of the Institution of Naval Architects has awarded the premium of the Institution for the year 1937 to Mr. R. W. L. Gawn, for his paper "Results of Experiments on Model Screw Propellers with Wide Blades", the Wakeham Prize (1937) to Mr. H. Lackenby, for his paper "Re-analysis of William Froude's Experiments on Surface Friction and their Extension in the Light of Recent Develop. ments", and the Duke of Northumberland Prize (1937) (awarded by the Council of the Institution in connexion with the award of National Certificates in Naval Architecture) to Mr. D. N. Wallace, of the Royal Technical College, Glasgow.

\section{International Federation of Eugenic Organizations}

THE report of the Twelfth Conference of the International Federation of Eugenic Organizations, held at Scheveningen, Holland, in July 1936, has just been issued, and can be obtained from W. P. van Stockum and Zn., N.V., The Hague, Holland, price three Dutch florins. A list of the fifty delegates from twenty countries is followed by twenty-five papers presented at the meetings. The papers range from the classification and inheritance of mental defects to mutations in plants and man, twin studies and the problems of sterilization in Germany, Denmark, Sweden and the United States. The 119 pages end with a report of the Human Heredity Bureau and also reports on the standardization of measurements in anthropometry, physiometry, psychometry and on racial psychiatry.

\section{Fifth International Congress for Experimental Cytology}

THE fifth Congress for Experimental Cytology will be held in Zurich on August 7-12, 1938. The sixteenth International Physiological Congress and the Intermational Veterinarian Congress will be held in Zurich too, on August 14-18 and August 21-25 respectively. The proceedings of the Cytological Congress are not to be divided in sections, but will be organized in the following way : Scientific sessions will take up seven half days; two afternoons are reserved for demonstrations, and during one afternoon there will be an excursion. Special subjects are to be treated at each session, opening with a general 